\section{Journal of Educational \\ Technology \& Online Learning}

Volume 3 | Issue 3 | 2020

https://dergipark.org.tr/tr/pub/jetol

\title{
Role of Emerging Technology on Academic Achievement of Students at The University of Cape Coast
}

\author{
Desire Mawuko Komla Ayite \\ Paul Nyagorme $(\mathrm{PhD})^{\mathrm{b}}$ \\ adesire.ayite@stu.ucc.edu.gh, University of Cape Coast, Cape Coast, Ghana, ORCID 0000-0001-8049-3578 \\ bnyagorme@ucc.edu.gh. University of Cape Coast, Cape Coast, Ghana, ORCID 0000-0002-8941-7413
}

Doi: $10.31681 /$ jetol.733397

Suggested citation: Ayite, D. M. K., \& Nyagorme, P. (2020). Role of emerging technology on academic achievement of students at the University of Cape Coast. Journal of Educational Technology \& Online learning, 3(3), 272-287.

\section{Article Info}

Received : 06.05 .2020

Revised : 27.05 .2020

Accepted: 14.06 .2020

Research Article

\begin{abstract}
The main aim of this study was to find out how emerging technologies influence academic achievement of students at the University of Cape Coast. The study employed ex post facto research design utilizing quantitative approach for data collection. Findings from the data analyzed showed that emerging technologies are available for use in the various departments of the University. For instance, mobile phones (93.8\%), internet $(88.8 \%)$, laptops/desktops $(86.8 \%)$, projectors $(82.1 \%)$, electronic books $(68.1 \%)$, Tablets $(62.2 \%)$ and online courses $(50.4 \%)$ were available and accessible to more than half of the respondents. It was also found that mobile phones, laptops/desktops, Intelligent Personal Assistants (IPAs), projectors, e-books, internet, and e-learning lab equipment were evenly distributed across the departments while the rests were not evenly distributed as there were statistically significant differences among their availability across the various departments. In addition, the study found that there is negative relationship on the extent to which respondents use emerging technologies and their academic performance. However, the use of the internet recorded a statistically significant relationship with p-value of 0.040 . The study recommends that students must make a conscious effort to use the emerging technologies available in the university in order to be successful in their academic pursuits.
\end{abstract}

Keywords: Emerging technologies, educational/learning performance, academic achievement, education, distractor

\section{INTRODUCTION}

All over the world, education is considered the key to development. There is no doubt that education has evolved over the years. With it comes all kinds of technologies students are using to facilitate the acquisition of knowledge. Prasad (2016) indicated that the influence of emerging 
technology is felt in almost all the developed countries. There is a growing consensus that developing countries are also feeling the effect of the emerging technologies on every facet of their lives.

As humans continue to develop creative ways of doing things, so do the tenets of education. Thus, over the centuries, there is a constant change in the teaching and learning methodologies. Mapotse (2014) posited that due to the development in science and technology in the world, there has been a change and the rate of change continues to accelerate at a pace of increasing magnitude. Teaching and learning methodologies are constantly changing based on the technology presence at each developmental stage of education.

Educational technology has changed the face of education over the years. According to Ouyang and Stanley (2014), educational technology over the past 50 years has evolved rapidly. From a general point of view, it is common to say that every teaching and learning activity is influenced by the technology present at a given time.

In the past, most classroom teachers were limited to few resources or technology forcing them to adopt the teacher-centred (chalk and talk) approach. Thus, teachers are normally found to do most of the talking while students watch and listen passively to the information being delivered (Ottevanger, van den Akker \& de Feiter, 2007). Ottevanger et al. (2007) further stated that this type of teaching is mostly dominated by lots of note copying and scarcely any practical activities. Thus, students concentrate on note taking rather than trying to understand what is being taught. More often than not, the teacher-centred approach has been criticized due to its inability to produce high achieving students in science and science related subjects (Hartsell, Herron, Fang, \& Rathod, 2009). If the teacher-centred method is continuously criticized, it could mean that there are better ways of teaching students.

Emerging technology is often seen as the introduction of computers and the related technological devices into the educational arena. Normally, it should be noted that the inception of computers and other Information and Communication Technology (ICT) devices into the educational sector will cause some level of variation in the teaching and learning process.

What is worth pondering over is whether the integration of emerging technology has played any role in enhancing students' understanding of their subject matters. Granito and Chernobilsky (2012) noted that even though emerging technologies are gradually being integrated into the 
educational sector, the actual influence of using it in the instructional process is still unfamiliar. Teaching professionals are still baffling with the role of technology in the students' desired learning.

\section{Statement of the Problem}

In the teaching and learning process, technology lies at the core of the delivery of information to learners. The integration of emerging technology into the learning process is to help learners use the technology available to improve upon their academic achievement. According to Liu, Hsieh, Cho and Schallert (2006), there is proof that there is augmentation in achievement and self-efficacy when emerging technology is used. However, there is no consistent conclusion regarding the type and the combinations of the emerging technologies that lead to high academic achievement. In higher education context, some of the students seem to be still adamant to use technologies for learning as they need it in online classes. However, they may face with different/various obstacles. The findings of Ahmed, Chowdhury, Rahman and Talukder (2014) indicated that, despite the enormous technologies available, 242 private university students were facing academic difficulties and may eventually opt out of the school if there is no intervention organised for them. This implies that, higher education students are not making use of emerging technologies to supplement their learning.

Further, students in the University of Cape Coast are also facing similar challenges. According to the information obtained from Management Information System (MIS) (SRMIS, 2017) section of the University of Cape Coast, 1,751 students failed in the first semester while 1,610 students failed in the second semester out of the 19,055 who sat for the two semester examinations for the 2014/2015 academic year. Similar results were recorded for the 2015/2016 and 2016/2017 academic years respectively.

There a general perception that the failure rate is as result of lack of understanding, laziness towards studies, and time mismanagement. Generally, there exists a paucity of research in the domain of using the emerging technologies for academic work within the Ghanaian context. In light of this problem the study sought to uncover the role of emerging technology on the academic achievement of students at the University of Cape Coast.

\section{Research Objectives}

The study aimed at achieving the following objectives: 
1. To determine the differences in the types of emerging technologies used by students across departments for academic work at the University of Cape Coast.

2. To determine the extent to which emerging technologies influence the academic performance of students in the University of Cape Coast.

\section{Research Hypotheses}

The following hypotheses were tested at a significance level of 0.05 :

H01: There is no statistically significant difference between emerging technologies available across departments and their use for academic work at the University of Cape Coast.

H02: There is no statistically significant relationship between how often students use emerging technologies and their academic performance.

\section{Significance of the Study}

This study will help to bridge the gap in literature about the use of emerging technologies for academic purposes in the context of students in the University of Cape Coast. It seems there is little literature on the use of emerging technologies in the Central Region of Ghana or Ghana at large. Therefore, this study presents new and emerging technologies that have emerged over the years to and have found their use in academia. In addition, lecturers of the university may find the

recommendation usefully as the study will create awareness in the use of emerging technology to support education. This study also gives confidence to the students to use emerging technologies for their academic work as it establishes relationship between the two variables.

\section{CONCEPTUAL FRAMEWORK}

Figure 1. Diagrammatically depicts how the distractors affect the teaching and learning processes leading to achieving academic performance. The conceptual framework describes intervening variables that are likely to contribute or hinder academic performance. 


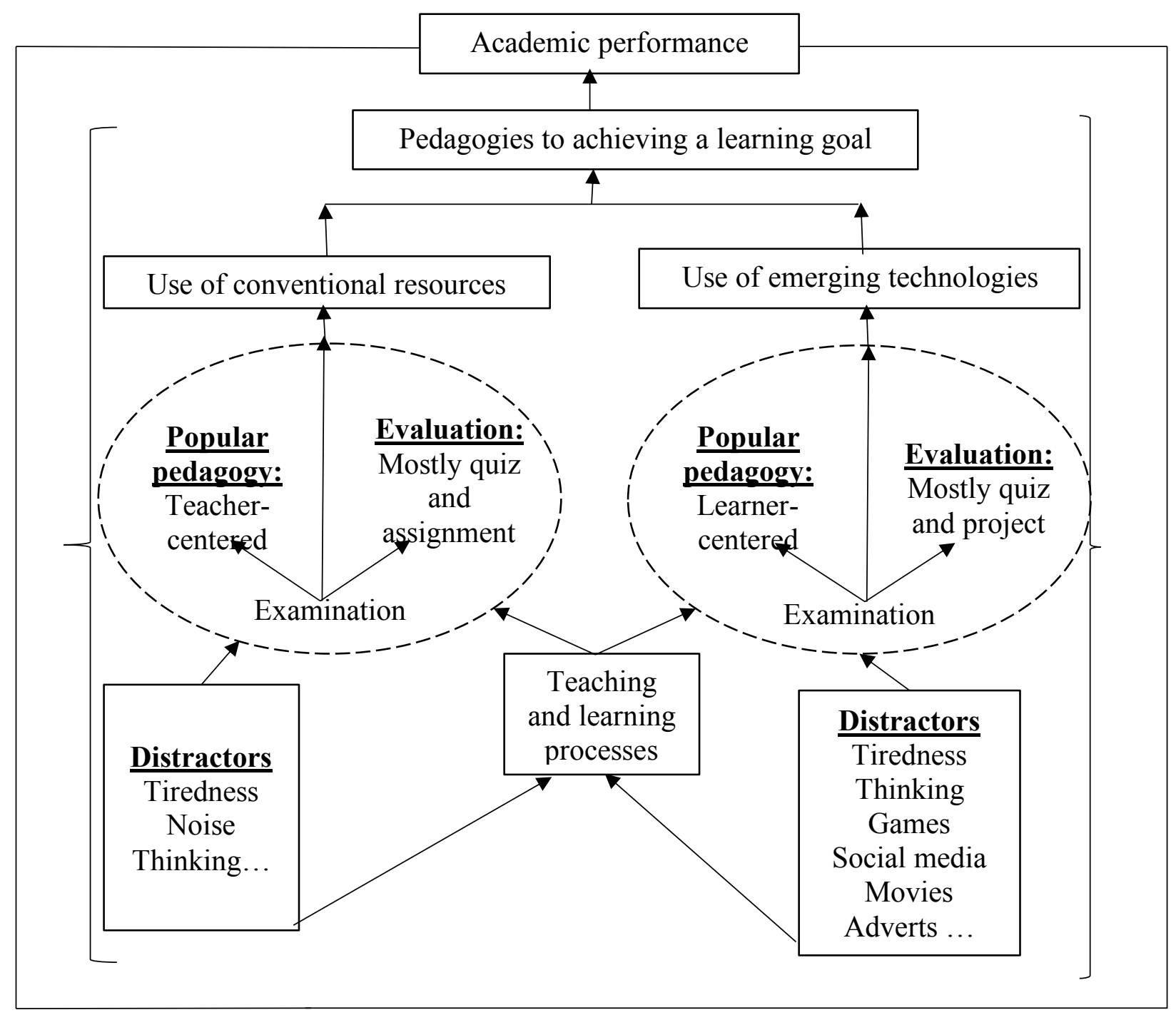

Figure 1. Conceptual framework

The main focus of Figure 1 is to identify variables that influence the teaching and learning processes. These factors are termed "distractors" because they interfere the learning activities. The researchers examined pedagogical approaches and compared traditional learning style with the emerging learning style adopted by learners. The framework is to make one understand how the learning contexts influence the choice of pedagogies. The pedagogies use in arriving at any educational goals can either be conventional (traditional) teacher-centred methods or the learnercentred methods via emerging technologies. That is, the conventional method used in achieving educational goals is seen by the researchers as mainly carried out through the teacher-centred approach with an emphasis on quizzes, assignments and examinations as the main methods of 
evaluation. These are seen as an individual based since most of these evaluation methods are limited to each individual student.

On the other hand, with the emerging technologies, educational goals are achieved by using the learner-centred approach or the constructivists approach with the evaluation methods being mainly quizzes, projects, and examinations. Most of these evaluations are somehow similar and also, these processes are not static but relative. This means they can change depending on the context in which they are being used.

In terms of external factors that distract students' learning, the researchers of the study are of the view that distractors are more in the use of emerging technology as compared to those of the conventional teaching approach. Thus, in the traditional learning environment, learners have few distractors when they really want to learn. On the contrary, there are more distractors when learners incorporate emerging technologies in their learning. Irrespective of the distractors, the researchers of the study want to identify the types of emerging technology students use and how they have effects on students' learning.

\section{METHODOLOGY}

The research design which guided this study was ex post facto. This design, according to Silva (2012), is a category of research design in which the "investigation starts after the fact has occurred without interference from the researcher" (p2). It starts with the observation and examination of facts that took place naturally, in the sense that the researcher cannot interfere but only explore the causes behind the evidence selected for analysis. Ex post facto design is relevant to this study because, the influence of emerging technologies on academic success of students seems to gain attention in the literature. What is missing and needs to be explored is to determine the types and the combinations of the emerging technologies that influence the academic successes of students.

Quantitative approach of data collection was used to gather data from 357 respondents constituting a response rate of $89.3 \%$. These students were selected using the stratified and cross-sectional sampling techniques based on the representativeness of the population as suggested by Krejcie and Morgan (1970). In addition, validity and reliability were ensured during the pilot study which gave a reliability coefficient, $\alpha=0.79$ from 50 students from the University of Education Winneba. 
However, for data analysis, the multiple response was also used to obtain percentage and frequencies on the availability of emerging technologies for students. For the research hypotheses, Chi-Square analysis tool was used for research hypothesis 1, and the Spearman Ranked Correlation Coefficient $(\rho)$ was used for research hypothesis 2 . These analysis tools were used as the normality assumption test was met. The sig. value for the normality test, $0.137>0.05$ which means that normality assumption is achieved.

\section{RESULTS AND DISCUSSION}

\section{Availability of Emerging Technologies across Departments}

Information obtained on the availability of emerging technologies in education is used to test for research Hypothesis 1. This information was obtained from section B of the research questionnaire used. The available technologies in all departments are tabulated in Table 1.

Table 1

Available Emerging Technologies in Departments $(\mathrm{N}=357)$

\begin{tabular}{|c|c|c|}
\hline Items & $\mathbf{N}$ & Case Percent \\
\hline Mobile phone (Smartphones) & 335 & $93.8 \%$ \\
\hline The internet & 317 & $88.8 \%$ \\
\hline Laptops and Desktops & 310 & $86.8 \%$ \\
\hline Projectors & 293 & $82.1 \%$ \\
\hline Electronic books & 243 & $68.1 \%$ \\
\hline Tablets (Android, iPads) & 222 & $62.2 \%$ \\
\hline Free online courses/learning platforms & 180 & $50.4 \%$ \\
\hline IPAs & 73 & $20.4 \%$ \\
\hline Cloud computing & 73 & $20.4 \%$ \\
\hline Projectors and laptops & 42 & $11.8 \%$ \\
\hline E-learning lab equipment & 25 & $7.0 \%$ \\
\hline Calculator & 16 & $4.5 \%$ \\
\hline
\end{tabular}

Source: Field survey, Ayite \& Nyagorme (2018)

At a glance, it can be seen that some technological tools recorded higher values than others. From Table 1, it is indicated that mobile phones (smartphones) are the commonest devices among students; this was revealed by $335(93.8 \%)$ out of 357 respondents. The internet which can be easily accessed with the phone, laptops and desktops, and projectors were indicated by 317 $(88.8 \%), 310(86.8 \%)$, and $293(82.1 \%)$ to be readily available for use respectively. Also, electronic books (e-books), tablets, and free online courses/learning platforms were shown by 243 
(68.1\%), $222(62.2 \%)$ and $180(50.4 \%)$ to be available respectively. These emerging technological resources were indicated by more than half of the respondents.

From other researches, emerging technologies are common in developing countries. This is not surprising since according to records, $75 \%$ of those who subscribed to mobile devices are in developing countries (Parsons, 2014). It also appears that most of the respondents use mobile phone technology to access other resources such as the internet, e-books, online courses among others. This information is in line with the statement made by AlTameemy (2017) that mobile phones can be used for academic purposes by making use of instructional technology and applications. In one way or another, each student needs to access information on the internet at one point in time. If nothing at all, each student needs to register courses every semester, check results, and view his/her examination time table on the students' online portal using mobile phones The use of some emerging technologies recorded limited use among students. That is, these technological tools are used by less than a quarter of the respondents. For emerging technologies such as Intelligent Personal Assistants (IPAs) and cloud computing were being used by $20.4 \%$ of the respondents. Also, as indicated in Table 4, even though laptops/desktop computers and projectors are readily available as shown by $86.8 \%$ and $82.1 \%$ of the respondents respectively, their utilisation in presentations is minimal (11.8\%). Further, e-learning lab equipment and calculators were the least named by the respondents of the study; $7.0 \%$ and $4.5 \%$ respectively.

From these results, one could say that there are limitations in the use of the resources available at the disposal of teachers and students. Considering the availability of mobile phones, laptops/desktops and cloud computing, only few students indicated that these devices are available. Contrary to the low responses recorded for IPAs, cloud computing, e-learning lab equipment, Kim and $\operatorname{Kim}(2016)$ recorded higher values (60.9\%) for the availability and use of cloud computing services. Likewise, IPAs are noted to be integral part of the K-12 educational system (Son, Kim, $\&$ Park, 2004). This means that much needs to be done by students to increase the level of use of cloud computing and IPAs. The availability of these devices may vary across departments.

\section{Testing of Hypothesis One}

H01: There is no statistically significant difference between emerging technologies available across departments and their use for academic work at the University of Cape Coast. 
Chi-Square analysis tool was used for research hypothesis 1 and the results revealed that there were significant differences in the emerging technologies used by students across departments as presented in Table 2.

Table 2

Chi-Square Values for the Availability of Emerging Technologies across Departments - Part 2 $(\mathrm{N}=357)$

\begin{tabular}{|c|c|c|c|}
\hline & Value & $\mathrm{df}$ & $\begin{array}{c}\text { Asymp. Sig. (2- } \\
\text { sided) }\end{array}$ \\
\hline \multicolumn{4}{|c|}{ Tablets (Android, iPads) * Department } \\
\hline Pearson Chi-Square & 15.209 & 4 & 0.004 \\
\hline Likelihood Ratio & 15.152 & 4 & 0.004 \\
\hline Linear-by-Linear Association & 3.650 & 1 & 0.056 \\
\hline \multicolumn{4}{|c|}{ Free online courses/learning platforms * Department } \\
\hline Pearson Chi-Square & 14.525 & 4 & 0.006 \\
\hline Likelihood Ratio & 14.668 & 4 & 0.005 \\
\hline Linear-by-Linear Association & 3.260 & 1 & 0.071 \\
\hline \multicolumn{4}{|l|}{ Cloud computing * Department } \\
\hline Pearson Chi-Square & 11.400 & 4 & 0.022 \\
\hline Likelihood Ratio & 11.757 & 4 & 0.019 \\
\hline Linear-by-Linear Association & 0.827 & 1 & 0.363 \\
\hline \multicolumn{4}{|c|}{ Projector and laptops * Department } \\
\hline Pearson Chi-Square & 10.267 & 4 & 0.036 \\
\hline Likelihood Ratio & 9.679 & 4 & 0.046 \\
\hline Linear-by-Linear Association & 8.318 & 1 & 0.004 \\
\hline \multicolumn{4}{|l|}{ Calculator * Department } \\
\hline Pearson Chi-Square & 26.293 & 4 & 0.000 \\
\hline Likelihood Ratio & 26.721 & 4 & 0.000 \\
\hline Linear-by-Linear Association & 12.623 & 1 & 0.000 \\
\hline
\end{tabular}

From Table 2, the Chi-Square results on the availability of emerging technologies across departments were presented. The results presented a difference in the availability of emerging technologies across department since $\mathrm{p}<0.05$. Based on the results from Table 2 , there is a statistically significant difference in the availability of emerging technologies in terms of tablets (Android, iPads), $x 2(4, N=357)=15.209, p=0.004$; free online courses/learning platforms, $x 2$ 
$(4, \mathrm{~N}=357)=14.525, \mathrm{p}=0.006$; cloud computing, $\mathrm{x} 2(4, \mathrm{~N}=357)=11.400, \mathrm{p}=0.022$; projector and laptops, $\mathrm{x} 2(4, \mathrm{~N}=357)=10.267, \mathrm{p}=0.036$; and calculator, $\mathrm{x} 2(4, \mathrm{~N}=357)=26.293, \mathrm{p}=$ 0.000 .

These results indicated that emerging technologies such as tablets, free online courses, cloud computing, projectors and laptops, and calculators differ significantly from department to department. Though, literature did not show the difference in the availability of the named emerging technologies across departments, it was noted that tablet computing, collaborative webs, Massive Open Online Courses (MOOC) were expected emerging technologies that helped to open learning environments (Holotescu, 2015). The results obtained from the Chi-Square analysis indicated that there is a significant difference in the availability of the emerging technologies across the departments used in the study. Based on this, it is imperative to reject the null hypothesis (H01). The differences of these emerging technologies in the various departments could be due to the fact that some of the departments do not fully integrate or encourage their students to use any of the emerging technologies for learning

\section{Influence of the Extent of Use of Emerging Technologies on Students Academic success.}

H02: There is no statistically significant relationship between how often students use emerging technologies and their academic performance.

This hypothesis was tested using the Spearman Ranked Correlation Coefficient ( $\rho)$. This statistical tool was used because the variables involved are ranked and continuous. Table 3 presents the results obtained from the analysis.

\section{Table 3}

Correlation on the Extent of Use of Emerging Technologies and Academic Performance

\begin{tabular}{lcc}
\hline Items & $\begin{array}{c}\text { S } \\
\text { (2- } \\
\text { tailed) }\end{array}$ & 0.904 \\
\hline $\begin{array}{l}\text { I use services provided by messaging apps such as WhatsApp to get relevant academic } \\
\text { information }\end{array}$ & 0.006 \\
$\begin{array}{l}\text { I participate in my class online group discussions } \\
\text { I read e-books with emerging technological tools to get more understanding of concepts }\end{array}$ & 0.081 \\
& 0.038 \\
$\begin{array}{l}\text { I research, type, complete and submit my assignments and projects using emerging } \\
\text { technological tools }\end{array}$ & 0.067 \\
\hline
\end{tabular}




\begin{tabular}{|c|c|c|}
\hline I watch tutorials and videos on difficult concepts & -0.044 & 0.405 \\
\hline I use emerging technological tools to access information on the internet & 0.109 & 0.040 \\
\hline Emerging technological tools allow me to use multimedia resources when learning & 0.082 & 0.121 \\
\hline I usually compare lecturer's lessons to online information & 0.006 & 0.904 \\
\hline I take online courses easily with the aid of technological tools & 0.045 & 0.401 \\
\hline $\begin{array}{l}\text { I watch educational movies and play educational games more than I learn with emerging } \\
\text { technologies }\end{array}$ & -0.028 & 0.597 \\
\hline I use online cloud accounts to backup my educational documents & -0.049 & 0.352 \\
\hline
\end{tabular}

Source: Field survey, Ayite \& Nyagorme (2018)

When the items presented in Table 3 were correlated against academic performance, only weak relationships were obtained and only one of them is statistically significant. The extent to which respondents use services provided by messaging apps such as WhatsApp to get relevant academic information recorded a correlation coefficient $\rho=0.006$ and a significant value, sig. $=0.904$. This implies that there is a weak positive relationship between the two variables, but the relationship is not significant to conclude that there is an established relation between the two variables.

Similar situations were obtained for participating in class online group discussions, $\rho=0.038$, sig. $=0.471$; reading e-books, $\rho=0.081$, sig. $=0.127$; doing assignments with the help of emerging technological tools, $\rho=0.067$, sig. $=0.204$ among others. Moreover, a weak negative relationship was obtained on the extent to which some of the variables were used. The variables that correlated negatively against academic performance include watching tutorials and videos on difficult concepts, $\rho=-0.044$, sig. 0.405; watching educational movies and playing educational games more than learning with emerging technologies, $\rho=-0.028$, sig. $=0.597$; and using online cloud accounts to backup educational documents, $\rho=-0.049$, sig. $=0.352$. On the other hand, for the item "I use emerging technological tools to access information on the internet," $\rho=0.109$ and a sig. $=0.040$ was obtained. This implies that there is a statistically significant relationship between the extent of use of emerging technology to access information on the internet.

The findings of this study revealed only small relationships between the extent to which the use of variable involved influence academic performance even though only one of them is statistically significant. This finding confirms the results of Weaver (2000) that there exists only a small 
relationship between computer use and the students' performance in mathematics, science and reading with a correlation coefficient of 0.035 . Contrarily, (BECTA) as cited in Elohor (2013) revealed that there is no relationship between emerging technology resources and either reading or mathematics. Students' performance could actually depend on how students are committed to learning than the resources available to them.

The use of emerging technologies in learning could be considered as a minor element of learning since only small or no relationships is obtained from their use on academic performance. As BECTA indicated that the relationship of the variables used in the study carried out exceeded 0.07 , this study found that the highest relationship obtained is 0.109 on students use of emerging technologies to access information on the internet.

Therefore, it is evident to reject the null hypothesis that there is no statistically significant relationship between how often students use emerging technologies and their academic performance since one of the significant values obtained is less than the critical value 0.05 .

\section{Contribution to Literature:}

Finding 1a: The research found that the emerging technologies used by the respondents were more than the number of respondents that took part in the study which implies that some students possess more than one technological device. Smartphone dominates all other emerging technologies used by the respondents $(341,95.5 \%)$ while IPAs recorded the lowest number $(5,1.4 \%)$.

Finding 1b: Also, mobile phones (93.8\%), internet (88.8\%), laptops/desktops (86.8\%), projectors (82.1\%), electronic books (68.1\%), Tablets $(62.2 \%)$ and online courses $(50.4 \%)$ were available and accessible to more than half of the respondents in the selected departments for the study. This means that respondents can make good use of these emerging resources whenever the need arises.

Finding 1c: From the emerging resources available to the respondents in the departments, it was found that mobile phones, laptops/desktops, IPAs, projectors, e-books, internet, and e-learning lab equipment were evenly distributed across the departments. There was no statistically significant difference between these resources across departments.

Finding 1d: On the other hand, it was found that tables, free online courses, cloud computing, projectors and laptops, and calculators differ from departments to departments. Some departments possess more of these devices than others. Even though projectors were noted to be evenly 
distributed across departments, their uses in the various departments differ significantly as the results obtained against them are statistically significant. Meanwhile, these devices recorded both weak negative and weak positive relationships across departments.

Finding 2: Again, the study found that there are weak relationships on the extent to which respondents use emerging technologies and their academic performance. Thus, there are positive and negative relationships between the extent to which respondents use emerging technologies and their academic performance. Meanwhile, the extent to which emerging technologies are used to find information on the internet was statistically significant with a p-value of 0.040 .

\section{CONCLUSION AND SUGGESTIONS}

Based on the findings of the study, it is evident to conclude that, the presence or availability of emerging technologies in the various departments does not automatically suggest that they will be used for learning by students. Learners must make conscious effort to integrate the emerging resources available into their learning styles if only they want to benefit from the advantages these resources present.

Once more, how often students use emerging resources available to them is not sufficient to tag them as agents of academic boosters. Emerging resources serve different purposes; therefore, if students use them for playing games, or watching movies among others, performance will go down instead of improving. The use of emerging technologies is not a green card to academic excellence but how effective learners use it to learn.

Based on the findings of the study, there is a need to educate students on effective use of emerging technologies to solve academic problems. According to the information obtained from the study, most students are of the view that learning the traditional way benefits them more than when they use emerging technologies in learning. 


\begin{abstract}
Yeni Teknolojilerin Cape Coast Üniversitesindeki Öğrencilerin Akademik Başarısı Üzerinde Rolü

\section{Özet}

$\mathrm{Bu}$ çalışmanın temel amacı, yeni gelişen teknolojilerin Cape Coast Üniversitesindeki öğrencilerin akademik başarısını nasıl etkilediğini ortaya çıkarmaktır. Çalışmada nicel araştırma yöntemlerinden nedensel karşılaştırmalı araştırma deseni kullanmıştır. Çalışma bulguları, yeni teknolojilerin üniversitenin pek çok bölümünde kullanılabileceğini göstermektedir. Bu bağlamda, üniversitede; cep telefonu $(\% 93,8)$, internet $(\% 88,8)$, dizüstü / masaüstü bilgisayarlar $(\% 86,8)$, projektörler $(\% 82,1)$, elektronik kitaplar $(\% 68,1)$, tabletler $(\% 62,2)$ ve çevrimiçi derslerin $(\% 50,4)$ katılımcıların yarısından fazlası tarafından erişilebilir durumda olduğu görülmüștür. Ayrıca cep telefonları, dizüstü bilgisayarlar / masaüstü bilgisayarlar, akıllı kişisel asistanlar, projektörler, e-kitaplar, internet ve e-öğrenme laboratuvarı ekipmanlarının bölümler arasında eşit olarak dağıtıldığı, geri kalanların ise eşit olarak dağıtılmadığı da tespit edilmiştir. Buna ek olarak, sonuçlar öğrencilerin yeni teknolojileri kullanım düzeyleri ile akademik başarıları arasında olumsuz yönde bir ilişki olduğunu ortaya koymuştur. Bununla birlikte, internet kullanımı istatistiksel olarak anlamlı bir ilişki göstermiştir. Sonuç olarak çalışma, öğrencilerin akademik hayatlarında başarılı olmak için üniversitede mevcut olan yeni teknolojileri kullanmaları konusunda bilinçli bir çaba sarf etmelerini önermektedir.
\end{abstract}

Anahtar kelimeler: Yeni teknolojiler, öğrenme performansı, akademik başarı, eğitim, çeldirici

\begin{abstract}
About the Authors
Desire M. K. Ayite

Desire M. K. Ayite is a teacher at the University Basic School of the University of Cape Coast - UCC (Ghana) and also a graduate of M.Ed. Information Technology from UCC. He also holds B.Ed. Computer Science degree from the same university. While working as a teacher, Desire has the ambition of pursuing his education to the $\mathrm{PhD}$ level and also contribute to the development of information technology/computing education in Ghana and the world at large. He is also interested in conducting research in educational technology, online learning, cloud computing and other research studies in Information Technology.
\end{abstract}

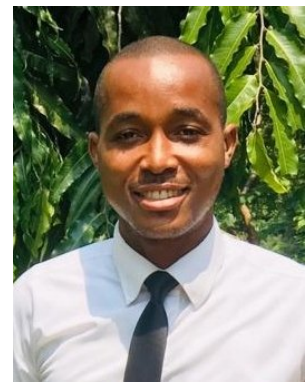

desire.ayite@stu.ucc.edu.gh, University of Cape Coast, Cape Coast, Ghana, +233

\title{
Paul Nyagorme (PhD)
}

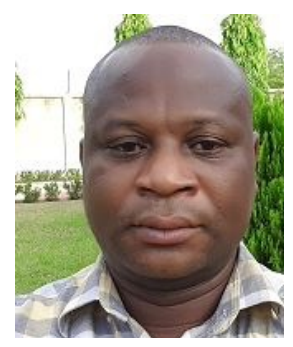

Paul Nyagorme holds a terminal degree in Educational Technology in Kenyatta University, Kenya, Nairobi. He also graduated in Master of Education (Information Technology) and Master of Arts (Religion and Human Values), all from the University of Cape Coast, Ghana. Dr. Nyagorme is very wellinformed in the theories, practices and research in the field of educational technology, multimedia usage, adoption and utilization of eLearning, usage of open-source resource for distance education. He is an expert in eLearning site development, deployment and management. He has considerable experience in face to face teaching and online facilitation.

pnyagorme@.ucc.edu.gh, University of Cape Coast, Cape Coast, Ghana, +233 


\section{REFERENCES}

Ahmed, J. U., Chowdhury, Md. H. K., Rahman, S., \& Talukder, A. K. M. M. H. (2014). Academic Probation: An empirical study of private university students. Research in Education, 92(1), $1-17$.

AlTameemy, F. (2017). Mobile phones for teaching and learning: Implementation and students' and teachers' attitudes. Journal of Educational Technology, 45(3), 437-451.

Elohor, O. O. (2013). A technological approach to impactive learning. International Journal of Science and Research, 4(5), 901-912.

Granito, M., \& Chernobilsky, E. (2012). The Effect of Technology on a Student's Motivation and Knowledge Retention. NERA Conference Proceedings 2012. 17.

Hartsell, T., Herron, S., Fang, H., \& Rathod, A. (2009). Effectiveness of professional development in teaching mathematics and technology applications. Journal of Educational Technology Development and Exchange, 2(1), 53-56.

Holotescu, C. (2015). A conceptual model for Open Learning Environments (Conference paper). Retrieve from https://www.researchgate.net/profile/Carmen_Holotescu/publication/ 282158171_A_conceptual_model_for_Open_Learning_Environments/links $/ 5605 \mathrm{cl}$ fb08a ea25fce $3408 \mathrm{cb} / \mathrm{A}$-conceptual-model-for-Open-Learning-Environments.pdf?origin= publication_list\&ev=srch_pub_xdl.

Kim, S-H., \& Kim J. K. (2016). Determinants of the adoption of mobile cloud computing services: a principal-agent perspective. Information Development, 34(1), 44-63.

Krejcie, R. V., \& Morgan, D. W. (1970). Determining sample size for research activities. Educational and Psychological Measurement, 30, 607-610.

Liu, M., Hsieh, P., Cho, Y., \& Schallert, D. (2006). Middle school students' self-efficacy, attitude, and achievement in a computer-enhanced problem-based learning environment. Journal of Interactive Learning Research, 17(3), 225-242.

Mapotse, T. A. (2014). Action Research with Technology Education Teachers: Experiences Gained during Learners Projects Supervision Process. Mediterranean J. Social Sci., 5(2), 103-109.

Ottevanger, W., Akker, J. J. H., \& de Feiter, L. (2007). Developing Science, Mathematics and ICT education in sub-Saharan Africa (SMICT): Patterns and promising practices. Paper presented at the World Bank Working Paper. 
Ouyang, J. R., \& Stanley, N. (2014). Theories and Research in Educational Technology and Distance Learning Instruction through Blackboard. Universal Journal of Educational Research, 2(2), 161-172.

Parsons, D. (2014). The future of mobile learning and implications for education and training. In M. Ally \& A. Tsinakos (Eds.), Increasing learning through mobile learning (pp. 217-229). Vancouver, BC: Commonwealth of Learning and Athabasca University

Prasad, A. N. (2016). Impact of Modern Technology on Higher Education Role of ICT in Language Teaching. Unpublished Paper: Department of Collegiate Education, Bangalore. sagepub.com/base/download.xml

Silva C. N. (2012). Encyclopaedia of Research Design "Ex Post Facto Study" SAGE Publications, Inc. Thousand Oaks. Retrieved 20/12/19 from https://methods.

Son, C., Kim, M., \& Park, S. (2004). The case analysis of PDA integrated classroom. Proceedings of the Association for the Advancement of Computing in Education (AACE) SITE 2004 World Conference. Atlanta, Georgia.

Weaver, G. C. (2000). An examination of the national educational longitudinal study database to probe the correlation between computer use in school and improvement in test scores. Journal of Science and Technology, 9(2), 121-133. 